\title{
Estimates of suicide mortality in women residents in northeast brazilian states from 1996 to 2018
}

\author{
Estimativas de mortalidade por suicídio em mulheres residentes \\ nos estados do nordeste brasileiro de 1996 a 2018
}

Eder Samuel Oliveira Dantas (http://orcid.org/0000-0002-6595-6105) ${ }^{1}$

Yanna Madsan Fernandes Farias (https://orcid.org/0000-0001-9183-2475) ${ }^{2}$

Ezequiel Benigno Rezende (https://orcid.org/0000-0001-6350-5100) ${ }^{2}$

Glauber Weder dos Santos Silva (http://orcid.org/0000-0002-0570-1944) ${ }^{3}$

Pedro Gilson da Silva (https://orcid.org/0000-0002-3888-5807) ${ }^{1}$

Karina Cardoso Meira (http://orcid.org/0000-0002-1722-5703) ${ }^{4}$
${ }^{1}$ Hospital Universitário Onofre Lopes, Universidade Federal do Rio Grande do Norte (UFRN). Av. Nilo Peçanha 620, Petrópolis. 59012-300 Natal RN Brasil.edersamuel_rn@ hotmail.com

${ }^{2}$ Graduação em Gestão Hospitalar, UFRN. Natal RN Brasil.

${ }^{3}$ Departamento de Enfermagem, UFRN. Natal RN Brasil.

${ }^{4}$ Escola de Saúde, Universidade UFRN. Natal RN Brasil.

\begin{abstract}
The objective of this study was to analyze the temporal trend of suicide mortality in women in the states of Northeastern Brazil. This is an ecological study of a time series stratified by states in Northeast Brazil from 1996 to 2018, with data extracted from the Mortality Information System (SIM). The temporal trend was evaluated by negative binomial regression ( $p$ values $\leq 0.05$ ). There was a higher proportion of deaths in black and brown women (73.9\%), single (57.3\%), with the place of death occurring in the home (53.4\%). Hanging and strangulation stood out as the perpetration means (47.6\%). Most states showed an upward temporal trend, except for Pernambuco, Rio Grande do Norte, Sergipe and Maranhão, which showed a steady trend ( $p>0.05)$. An upward temporal trend was identified in the anal$y$ sis of deaths by suicide in women in five states in northeastern Brazil between 1996 and 2018. The information presented can support planning and decision-making for the prevention of suicide among women in northeastern Brazil.
\end{abstract}

Key words Suicide, Women, Time series studies
Resumo O objetivo deste estudo foi analisar a tendência temporal da mortalidade por suicídio em mulheres nos estados do Nordeste do Brasil. Trata-se de um estudo ecológico de uma série temporal estratificada por estados do Nordeste do Brasil de 1996 a 2018, com dados extraídos do Sistema de Informações sobre Mortalidade (SIM). A tendência temporal foi avaliada por regressão binomial negativa (valores de $p \leq 0,05$ ). Houve uma proporção maior de mortes em mulheres negras $e$ pardas (73,9\%), solteiras (57,3\%), com o local da morte ocorrendo em casa $(53,4 \%)$. Suspensão e estrangulamento se destacaram como o meio de perpetração (47,5\%). A maioria dos estados apresentou tendência temporal ascendente, com exceção de Pernambuco, Rio Grande do Norte, Sergipe e Maranhão, que apresentaram tendência estável $(p>0,05)$. Uma tendência temporal ascendente foi identificada na análise dos óbitos por suicídio em mulheres em cinco estados do Nordeste brasileiro entre 1996 e 2018. Assim, as informações apresentados podem apoiar no planejamento e nas tomadas de decisões para prevenção do suicídio entre mulheres no Nordeste brasileiro.

Palavras-chave Suicídio, Mulheres, Estudos de séries temporais 


\section{Introduction}

Suicide is a deliberate, conscious and intentional act of killing oneself. It is a complex and multidetermined phenomenon, which involves psychological, biological, social, environmental and cultural issues ${ }^{1}$. It is considered a serious public health problem in the world. Every year 800,000 suicides are reported worldwide, corresponding to $1.4 \%$ of all causes of death (11.4 deaths per $100,000$ inhabitants) $)^{2}$.

The highest suicide mortality rates in 2015 were observed in Southeast Asia and Europe, with mortality rates ranging from 11.9 to 14.0 deaths per 100,000 inhabitants. The lowest coefficients were observed in the Eastern Mediterranean (3.8 to 4.3 deaths per 100,000 inhabitants). In addition, $78 \%$ of suicides occurred in developing countries ${ }^{2}$.

There were 55,649 deaths from suicide (5.5 per 100,000 inhabitants) in Brazil between 2011 and 2015. The highest risk of suicide was observed in males (8.7/100 thousand men), representing about four times higher than the female coefficient $\left(2.4 / 100\right.$ thousand women) ${ }^{3}$, constituting a similar profile to that observed in other countries $^{4}$. However, the proportion of suicide attempts among women exceeds that of men. In a retrospective cohort conducted in Brazil, it was found that 535 of 803 cases of suicide attempts were female, representing $65.8 \%$ of the total ${ }^{5}$, thus signaling the importance of studying suicides in the female population ${ }^{6,7}$.

It was observed in a multicenter study which included 17 countries in Asia, Africa, Europe, America and the Middle East, that women at higher risk of suicide were single, young, less educated and had some mental disorder ${ }^{8}$. Regarding risk factors, traumatic events such as abortion, postpartum depression, eating disorders, lifelong depression and social isolation stood out ${ }^{9-11}$.

Considering the relativization of data due to population, territorial differences and the non-standardization of gross rates, it is highlighted that the suicide mortality rate in Brazilian women (2.4 deaths per 100,000 women) ${ }^{3}$ is 4 to 5 times lower than in countries with higher mortality rates from this cause (South Korea (11.40) and Japan $(7.94))^{4,12}$. The highest mortality rates are in the states of south-central Brazil, ranging from 2.7 to 4.9 deaths per 100,000 inhabitants ${ }^{3}$.

Although Brazilian rates are considered low-level rates by WHO $(<5.0$ deaths per 100,000 women), a study developed by Rodrigues et al. ${ }^{13}$ in Brazil showed an upward trend in female sui- cides between 1997 and 2015 in all age groups studied (15-29, 30-39, 40-59 and $\geq 60$ years); a result corroborated by the study of Alicandro et al. ${ }^{4}$.

In the same direction, although mortality rates due to female suicides in the Northeast have the lowest coefficients in Brazil, there was an upward trend in mortality trends in most of the states and age groups studied ${ }^{13}$. However, it is important to highlight that these coefficients may be underestimated due to the large proportion of deaths classified as undetermined intent (UD) (in Brazil and the Northeast, between 1996 and 2018, 250,233 and 69,641 (27.8\%) deaths whose intention was undetermined, respectively. In the Northeast, these data ranged from 1,668 (17\%) indeterminate deaths in 1996 to 3,569 $(29 \%)$ in 2018$)^{14-16}$. Moreover, it is noteworthy that this Brazilian region has great socioeconomic vulnerability and high income concentration, associated with the process of dissemination and internalization of violence in the $2000 \mathrm{~s}^{17}$.

Therefore, this article aims to analyze the temporal trend of suicide mortality in women in the states of northeastern Brazil.

\section{Methodology}

This is an ecological study of temporal tendency with the study population consisting of deaths of women by suicide in northeastern Brazil states from 1996 to 2018, in the age group of 10 to 60 or more years in women. The official data on mortality from suicide was obtained from the Information System on Mortality of the SUS Department of Informatics (SIM/DATASUS) on May 13, 2020.

Thus, due to the limitations in the quality of information on death records, and because there is no consensus in the literature on the best correction method to be used ${ }^{15}$, in this study we chose to use the methodology correction used by the Ministry of Health, in which the death records coded as suicide (X60 to X84) were added due to exogenous poisoning of undetermined intent (Y10 to Y19) and sequelae of intentional self-harm $(\text { Y87.0 })^{3,18,19}$.

Age-specific gross mortality rates were estimated and standardized by the direct method, using the World population proposed by the $\mathrm{WHO}^{20}$ as the standard population. Mortality coefficients were calculated by 100,000 women.

Death records were extracted according to race/color, place of occurrence and means by 
which the aggression was perpetrated. These characteristics were also obtained by adding the records classified as suicide, exogenous intoxication of undetermined intent and sequelae of intentional self-harm. Sociodemographic variables were categorized as: race/color - white, black/ brown, yellow and indigenous; civil status - single, married, legally separated, widowed and others. Furthermore, the place of death was stratified into: hospital; public highway; residence; another health facility; or others. The means of suicide perpetration was stratified into: chemical poisoning; hanging/strangulation; firearm, explosive devices; smoke, fire and flames; penetrating or blunt object; jumping from a high place; moving object, motor vehicle impact, or other means.

Relative frequencies for these variables were calculated for each Northeast state and bar graphs were constructed. The difference between the categories of each variable according to states and the Northeast region was evaluated by the Chi-squared and Fisher exact tests according to the distribution of the categories of the variables, considering statistically significant values of $\mathrm{p} \leq 0.05$.

The temporal trend analysis was performed in two stages: an exploratory analysis was initially performed using the autocorrelation function and the Durbin-Watson test to assess the autocorrelation of the historical series ${ }^{21}$. Once the temporal dependence of the data was confirmed, the temporal trend was evaluated by generalized linear models. Negative binomial regression was then used since the dependent variable (death count) presented overdispersion (greater than average variance).

In this analysis, the number of deaths expected for each year represented the dependent variable, while the centralized calendar year represented the independent variable. Weighted regression models were estimated as proportional to population size by adding the parameter known as offset, which represents the population logarithm of each locality under study ${ }^{21}$. These analyzes were performed in the $\mathrm{R}$ version 3.1.0 program through the MASS library, considering statistically significant values of $\mathrm{p} \leq 0.05$.

The historical series are classified as stationary, descending or ascending by the Relative Risk (RR) assessment and its respective $p$-value, namely: $R R>1$ and $p$-value $\leq 0.05$ - historical series classified as ascending; $R R<1$ and $p$-value $\leq 0.05$ - historical series classified as descending; RR greater than or less than 1 and p-value $>0.05$ - the historical series is classified as stationary.

\section{Results}

There were 9,742 deaths from suicide in women (2.00 deaths per 100,000 women) in the Northeast Region from 1996 to 2018. In this period $55.55 \%$ of the states had standardized suicide rates per 100,000 women higher than the Northeast coefficient, which are: Piauí (3.68 deaths), Sergipe (3.21 deaths), Ceará (2.95 deaths), Pernambuco (2.43 deaths) and Rio Grande do Norte (2.27 deaths).

In all states there was an increase in the percentage variation when comparing the mortality rates of the first (1996) and last year under study (2018), with the exception of the states of Pernambuco (-5.82\%) and Rio Grande do Norte $(-38.43 \%)$ that showed a reduction in the percentage variation when comparing the same periods. In this scenario, the states of Alagoas (326.76\%), Piauí (311.05\%) and Sergipe (568.55\%) stand out, with increases above $300 \%$ (data not shown).

The average mortality rates according to age group in the northeastern states are not uniform. The lowest rates are found in the age group of 10 to 14 years, then fluctuate with increases and decreases. There was a higher coefficient in the fourth decade of life in the states of Ceará and Sergipe, while in Maranhão and Paraíba in the fifth decade. Furthermore, there were higher coefficients in older adults in the states of Bahia, Pernambuco, Piauí, and Rio Grande do Norte (Figure 1).

Regarding sociodemographic variables, it was not possible to evaluate the distribution of deaths according to education due to the high proportion of deaths recorded as ignored, being higher than 30\% in the Northeast, ranging from 13.0\% in Maranhão to $79.50 \%$ in Alagoas.

There was a high frequency of deaths among women of African descent (black/brown) in all analyzed states $(\mathrm{p} \leq 0.05)$, ranging from $59.34 \%$ in Rio Grande do Norte to $87.09 \%$ in Alagoas. There was similarly a high proportion of deaths in single women $(\mathrm{p} \leq 0.05)$ in all locations (Figure 1). In all states there was a higher proportion of deaths in single women ranging from $47.79 \%$ in Piauí to $66.67 \%$ in Alagoas ( $\mathrm{p}=0,04)$ (Figure 2).

The place where suicide deaths occurred most frequently was the home followed by the hospital $(\mathrm{p}<0.001)$ in all states and in the Northeast region, except for Pernambuco, where it was the hospital followed by the home $(43.63 \%$ vs $41.26 \%, \mathrm{p}=0.06$ ) (Figure 3).

Regarding the perpetration means, there was a higher frequency of death by hanging and 


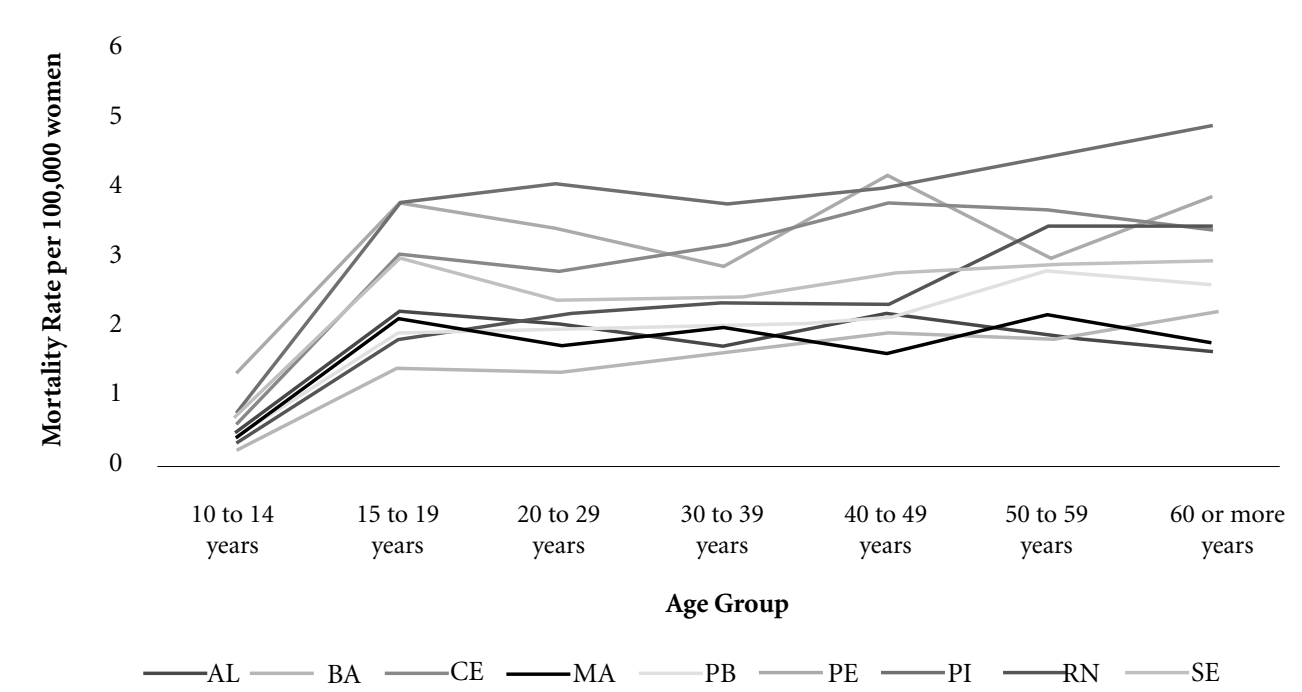

Figure 1. Average mortality rates according to age group in the states of the Northeast region, from 1996 to 2018.

Source: Mortality Information System (SIM/DATASUS).

strangulation $(\mathrm{p} \leq 0.05)$, ranging from $35.57 \%$ in Sergipe to $63.79 \%$ in Piauí, followed by deaths perpetrated by chemical substances, except for the state of Pernambuco, where chemical suicides followed by hanging/strangulation stood out (40.50\% vs. $32.91 \%$, p=0.003) (Figure 4). In suicides carried out by chemical substances, there was a higher proportion of deaths caused by pesticides in all localities $(\mathrm{p} \leq 0.05)$.

Regarding the temporal trend, there was an ascendancy profile in the Northeast region and in all its states, except for Pernambuco, Rio Grande do Norte, Sergipe and Maranhão, where the temporal evolution pattern was stationary. There was an upward trend in the Northeast Region in all age groups, while there was no temporal evolution pattern according to age group in the northeastern states (Table 1).

\section{Discussion}

In the Northeast region and in five of its nine states, there was an upward trend in suicide mortality rates. In addition, the highest proportion of deaths occurred in black women (black and brown), single, in the home with the main means of perpetration hanging and exogenous intoxication. The average mortality rate of the Northeast region represented 2.0 deaths per 100,000 wom- en, thus matching the national average mortality rate between 2011 and $2015(2.04 / 100,000)^{3}$.

The magnitude of mortality from suicide evidenced in the Northeast states is considered low by the WHO (<5.0 deaths per 100,000 women). However, six northeastern states (Piauí, Sergipe, Ceará, Pernambuco and Rio Grande do Norte) whose suicide rates of women standardized per 100,000 were higher than the average of the Northeast region (2.0 deaths), and similar to the rates observed in Mato Grosso do Sul (3.7/100,000 women), which had the highest rates in Brazil from 2011 to $2015^{3}$.

Despite the low magnitude of mortality rates in the Northeastern states when compared to the developed countries of Western Europe and Asia $^{4,12}$, the northeastern states show an upward trend in the evolution of suicide mortality in a large proportion (55.5\%), as well as Brazil in the period from 2004 to $2015^{22-24}$.

Similarly, mortality rates in the United States, Greece, the United Kingdom and Australia ${ }^{4,25}$ were rising in the 2000s. It is argued that this reality is correlated with the increased prevalence of mental health problems following the 2008 economic crisis, which increased unemployment, homeless people, and household indebtedness, among other factors ${ }^{4,26}$. The Northeast region represents one of the regions of greatest socioeconomic vulnerability in Brazil, and difficulties 
Status marital
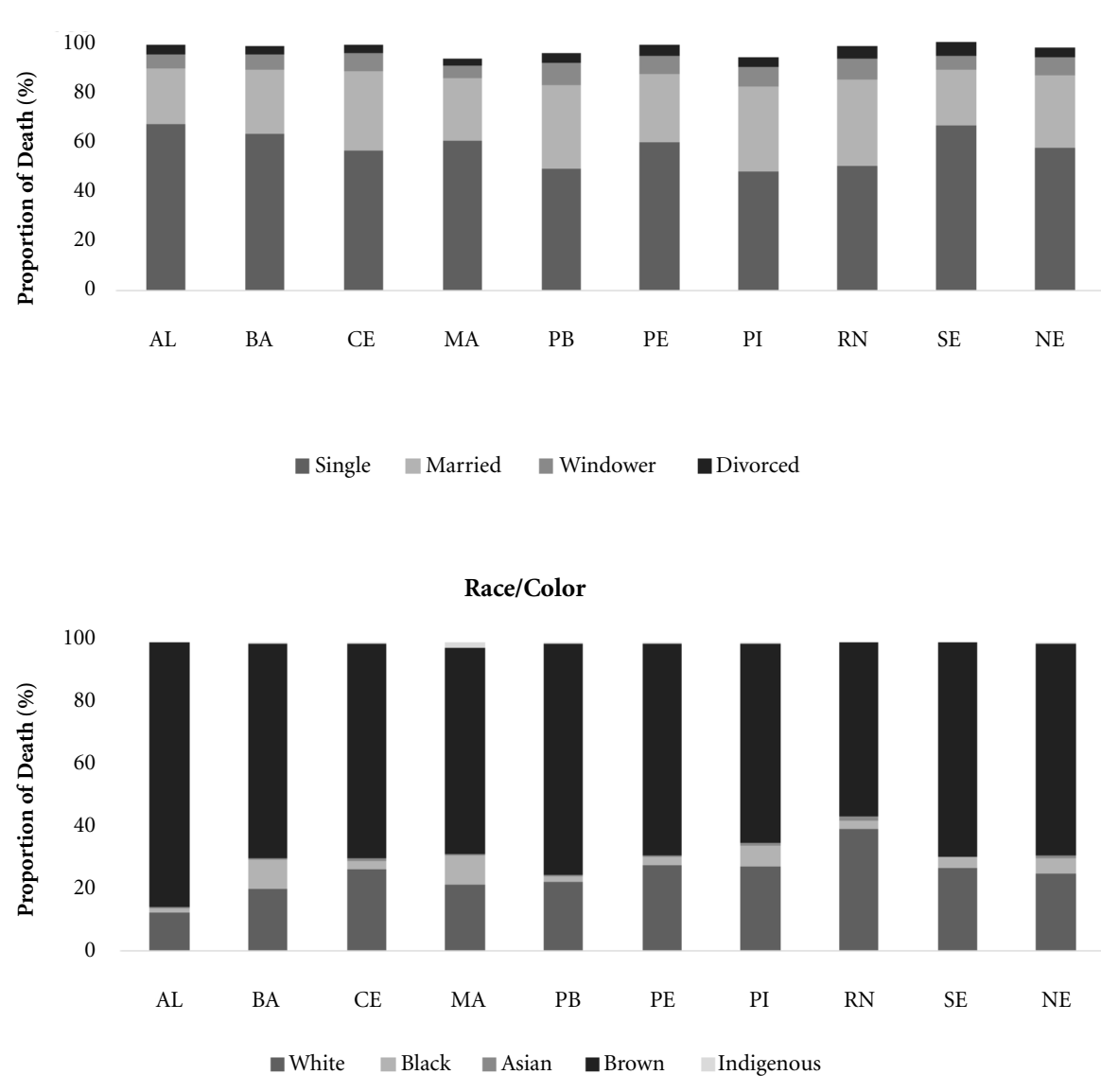

Figure 2. Proportion of deaths from suicide among women living in the states of Northeast Brazil, from 1996 to 2018, according to marital status and race/color.

Source: Mortality Information System (SIM/DATASUS).

in accessing health services, including mental health, constitute factors which may be contributing to the rise in suicide ${ }^{27}$.

Regarding the mortality trend by age group, there is an upward trend in women aged 60 and over in six states in the Northeast. This result is in agreement with that presented by other Brazilian studies ${ }^{13,28}$, which showed increased mortality from suicide in older adults. Suicide in older females occurs after various types of violence suffered throughout life. In addition, older women committed suicide after having strictly adhered to the gender role established by patriarchal society $^{10}$.

In the comprehensive context on suicidal behavior in older adult women in the Northeast Region ${ }^{9}$, it was identified that the attempt to com- mit the fatal act comes after a long journey of social isolation, depression, marital breakdown and family abandonment. And while suicide rates in Western/Occidental women are lower than in Eastern/Oriental women ${ }^{29}$, it is a fact that women are subject to greater social regulation and gender oppression, which in turn has an effect on self-harming behavior throughout the life cycle. In maintaining the scenario and violence cycles surrounding women, the Strategic Action Agenda for Suicide Surveillance and Prevention and Health Promotion in Brazil ${ }^{30}$ establishes a priority of addressing intimate partner violence prevention as one of the motivations for suicide based on gender relations.

Regarding the race/color of suicidal women in the studied region, the highest proportion 


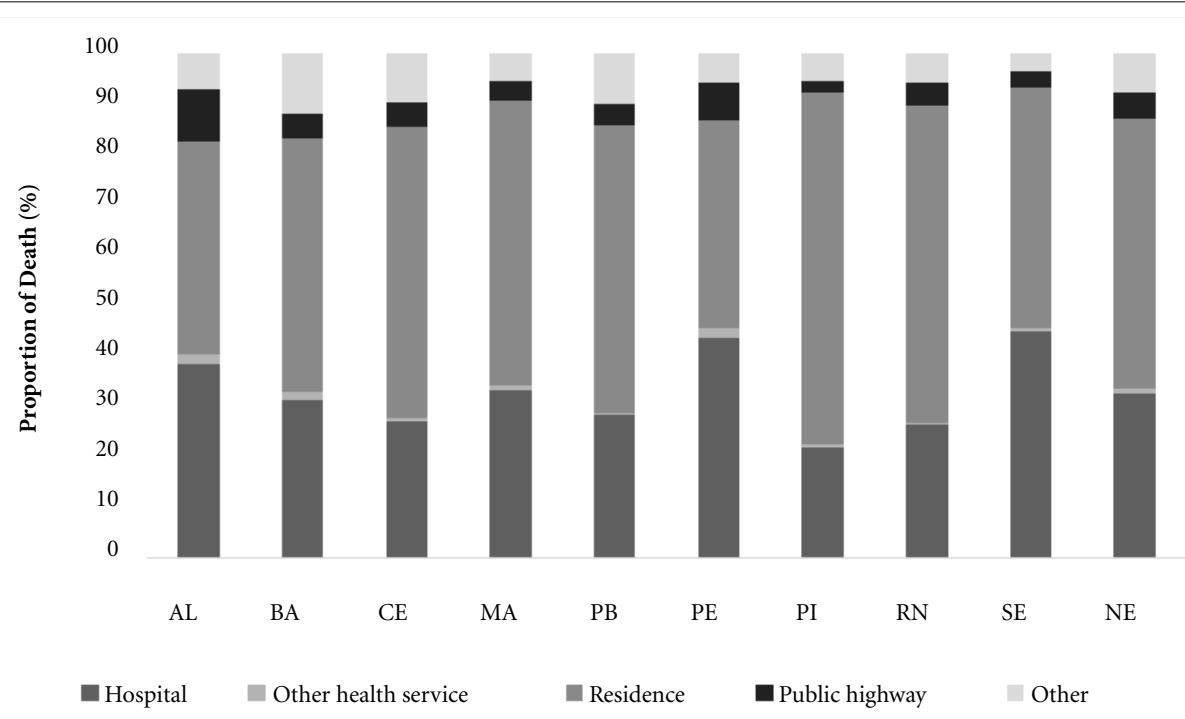

Figure 3. Proportion of deaths from suicide among women living in the states of Northeast Brazil, from 1996 to 2018, according to place of occurrence.

Source: Mortality Information System (SIM/DATASUS).

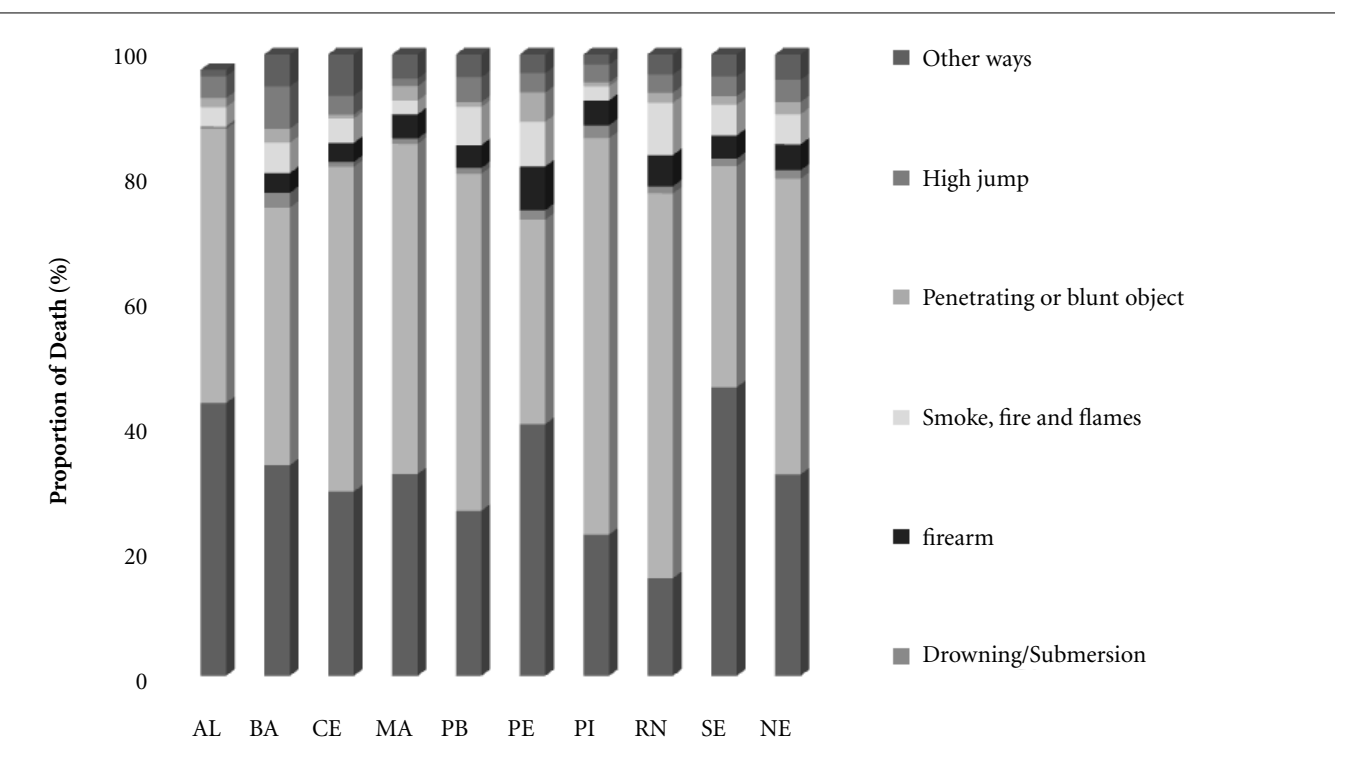

Figure 4. Proportion of deaths from suicide among women living in the states of Northeast Brazil, from 1996 to 2018, according to means of suicide perpetration.

Source: Mortality Information System (SIM/DATASUS).

of deaths in brown and black women is similar to that observed for Brazil in 2010, in which a higher suicide coefficient was observed in brown women $^{31}$.
There was a higher proportion of suicide deaths in single women in the Northeastern states, as shown in the Suicide Epidemiological Bulletin in Brazil ${ }^{3}$ and in an international study 
Table 1. Temporal trend of suicide mortality rates among women living in Northeastern states from 1996 to 2018, by state, age group and p-values.

\begin{tabular}{|c|c|c|c|c|c|c|c|}
\hline Age group (year) & $\mathbf{R R}$ & p-values & $\begin{array}{c}\text { Temporal } \\
\text { Trend }\end{array}$ & Age group (year) & RR & p-values & $\begin{array}{c}\text { Temporal } \\
\text { Trend }\end{array}$ \\
\hline $\mathrm{AL}$ & & & & BA & & & \\
\hline 10 to 14 & 0.99 & 0.966 & ST & 10 to 14 & 1.001 & 0.956 & ST \\
\hline 15 to 19 & 0.98 & 0.326 & ST & 15 to 19 & 0.99 & 0.803 & ST \\
\hline 20 to 29 & 1.05 & 0.0006 & UP & 20 to 29 & 0.98 & 0.61 & ST \\
\hline 30 to 39 & 1.003 & 0.847 & ST & 30 to 39 & 1.02 & 0.03 & UP \\
\hline 40 to 49 & 1.06 & 0.0004 & UP & 40 to 49 & 1.01 & 0.06 & ST \\
\hline 50 to 59 & 1.01 & 0.603 & ST & 50 to 59 & 1.03 & 0.002 & UP \\
\hline 60 or more & 1.02 & 0.381 & ST & 60 or more & 1.03 & $<0.0001$ & UP \\
\hline Total & 1.02 & 0.0005 & UP & Total & 1.02 & $<0.0001$ & UP \\
\hline $\mathrm{CE}$ & & & & MA & & & \\
\hline 10 to 14 & 0.99 & 0.687 & ST & 10 to 14 & 0.9 & 0.22 & ST \\
\hline 15 to 19 & 1.001 & 0.323 & ST & 15 to 19 & 0.97 & 0.534 & ST \\
\hline 20 to 29 & 1.003 & 0.577 & ST & 20 to 29 & 1.001 & 0.756 & ST \\
\hline 30 to 39 & 0.99 & 0.996 & ST & 30 to 39 & 0.98 & 0.516 & ST \\
\hline 40 to 49 & 0.98 & 0.733 & ST & 40 to 49 & 1.06 & 0.134 & ST \\
\hline 50 to 59 & 1.003 & 0.728 & ST & 50 to 59 & 0.98 & 0.594 & ST \\
\hline 60 or more & 1.02 & 0.005 & UP & 60 or more & 1.05 & 0.169 & ST \\
\hline Total & 1.001 & 0.03 & UP & Total & 1.001 & 0.678 & ST \\
\hline PB & & & & $\mathrm{PE}$ & & & \\
\hline 10 to 14 & 1.05 & 0.158 & ST & 10 to 14 & 0.98 & 0.416 & ST \\
\hline 15 to 19 & 1.06 & 0.001 & UP & 15 to 19 & 0.99 & 0.246 & ST \\
\hline 20 to 29 & 1.05 & $<0.0001$ & UP & 20 to 29 & 0.98 & 0.008 & DW \\
\hline 30 to 39 & 1.03 & 0.03 & UP & 30 to 39 & 0.99 & 0.672 & ST \\
\hline 40 to 49 & 1.05 & 0.001 & UP & 40 to 49 & 0.99 & 0.735 & ST \\
\hline 50 to 59 & 1.03 & 0.04 & UP & 50 to 59 & 1.001 & 0.33 & ST \\
\hline 60 or more & 1.04 & 0.04 & UP & 60 or more & 1.007 & 0.39 & ST \\
\hline Total & 1.05 & $<0.0001$ & UP & Total & 0.99 & 0.22 & ST \\
\hline PI & & & & RN & & & \\
\hline 10 to 14 & 1.05 & 0.111 & ST & 10 to 14 & 1.06 & 0.158 & ST \\
\hline 15 to 19 & 1.01 & 0.293 & ST & 15 to 19 & 0.98 & 0.55 & ST \\
\hline 20 to 29 & 1.04 & $<0.0001$ & UP & 20 to 29 & 1.001 & 0.921 & ST \\
\hline 30 to 39 & 1.01 & 0.332 & ST & 30 to 39 & 1.004 & 0.72 & ST \\
\hline 40 to 49 & 1.05 & $<0.0001$ & UP & 40 to 49 & 0.98 & 0.313 & ST \\
\hline 50 to 59 & 1.03 & 0.02 & UP & 50 to 59 & 1.01 & 0.359 & ST \\
\hline 60 or more & 1.04 & 0.003 & UP & 60 or more & 0.99 & 0.749 & ST \\
\hline Total & 1.03 & $<0.0001$ & UP & Total & 1.003 & 0.534 & ST \\
\hline SE & & & & $\mathrm{NE}$ & & & \\
\hline 10 to 14 & 1.04 & 0.107 & ST & 10 to 14 & 1.02 & 0.04 & UP \\
\hline 15 to 19 & 1.02 & 0.142 & ST & 15 to 19 & 1.01 & 0.02 & UP \\
\hline 20 to 29 & 0.98 & 0.293 & ST & 20 to 29 & 1.01 & 0.0001 & UP \\
\hline 30 to 39 & 0.98 & 0.166 & ST & 30 to 39 & 1.001 & 0.02 & UP \\
\hline 40 to 49 & 1.01 & 0.316 & ST & 40 to 49 & 1.02 & $<0.0001$ & UP \\
\hline 50 to 59 & 1.01 & 0.494 & ST & 50 to 59 & 1.02 & $<0.0001$ & UP \\
\hline 60 or more & 1.04 & 0.022 & UP & 60 or more & 1.03 & $<0.0001$ & UP \\
\hline Total & 1.001 & 0.104 & ST & Total & 1.02 & $<0.0001$ & UP \\
\hline
\end{tabular}

ST: Stationary mortality trend; UP: Upward Mortality trend; DW: Downward mortality trend.

Source: Elaborated by the authors. 
which covered 17 countries $^{8}$. Although marriage is not a guarantee of psychological, economic and social balance, the largest number of single women who commit suicide may present other deficits in social skills, which are related to difficulties in social interactions, dissatisfaction in relationships, presence of social anxiety and low self-esteem.

In this study, it was found that the highest frequency of female suicides during the decades analyzed occurred in households followed by hospitals. These facts can be better understood by social dynamics, since women have historically long been deprived of working outside the home and having equal spaces with men in politics and public settings, leaving them with household chores and to care for children. Moreover, in this same place of greater experiences of female life, it is also the largest scenario of self-destructive acts $^{32}$.

Regarding the hospital emerging as a place of high occurrence of female deaths, it is noteworthy that although only $22 \%$ of people who attempt suicide enter the emergency room in Brazil ${ }^{33}$, it is precisely women who have a higher frequency of suicide attempts, and in turn are more admitted to these services after their suicide attempt, which can result in death in the hospital setting.

Hanging and exogenous poisoning stood out regarding the perpetration means in suicides in northeastern women. Hanging accounted for $46 \%$ of suicide in the Northeast, ranging from $30.8 \%$ to $62.3 \%$, which is a similar proportion to Brazil's average between 2011 and 2015 (47.0\%). The high prevalence of deaths by this means has also been found in other parts of the world such as South Africa, in which it reached $41 \%$ in female suicide ${ }^{12}$. Hanging is a perpetration means with high lethality.

In relation to exogenous poisoning which includes medicines and pesticides, they in turn represent the main means used in suicide attempts by women in Brazil ${ }^{5,34}$, and represent the second cause of suicide death in women in the country and in the Northeast region and all its states. Therefore, in corroborating World Health Organization recommendations, reducing access to potentially lethal substances is one of the most effective ways to prevent intentional poisoning.

The low proportion of the use of firearms as a means of perpetrating female suicide in the states of the Northeast region from 1997 to 2016 and in Brazil from 2011 to 2015 may be due to the reduction in the circulation of firearms due to the impact effect of Law No. 10,826/2003, which in art. 6 "prohibits the possession of firearms throughout the national territory, except in exceptional cases" ${ }^{\prime 35}$.

It is noteworthy that due to the high degree of lethality of firearms, studies show that the ease of obtaining firearms increases the incidence of suicides $^{2,12,36}$. An American study found strong scientific evidence that decreasing the circulation of firearms also decreases the number of suicides in the population ${ }^{37}$.

Contrary to initiatives aimed at reducing the circulation of means of perpetrating suicide, the Brazilian State has approved measures for the mass release of previously banned pesticides, many of which are considered to be highly powerful and harmful to human health. In addition, the State has facilitated the possession of firearms for the general population which could increase the suicide rate in the country ${ }^{38,39}$.

The present study has as a limitation the quality of information on death records in the Mortality Information System, which can influence the trend and magnitude of suicide mortality rates. Studies have shown that there is poor quality of information, with deaths due to suicide being registered as an ill-defined cause, an event whose intent is undetermined, especially as unintentional exogenous intoxication, and in some cases they are not even registered in the $\operatorname{SIM}^{15,18,19}$. There is no consensus on the best methodology for the correction of death records to generate more reliable mortality coefficients $s^{15}$, however in the present study we sought to mitigate this limitation using the methodology used by the Ministry of Health.

\section{Conclusion}

An upward trend was identified in the analysis of the temporal trend of suicide deaths in women in Northeastern Brazilian states between 1996 and 2018. The information presented can support planning and decision-making for the prevention of suicide among women in northeastern Brazil, mainly to treat suicides of women in a region of the country that still has a difficult social and economic situation. In addition, it points to the need for further studies dealing with the correction of deaths by suicide, in view of this weakness in the Brazilian death data. 


\section{Collaborations}

ESO Dantas: conceived the study, wrote the manuscript, interpreted the data, reviewed the literature and approved the final version of the manuscript. YMF Farias: collected the data, reviewed the literature, wrote the manuscript and approved the final version of the manuscript. EB Rezende: designed the study, helped with data collection, and approved the final version of the manuscript. GWS Silva: helped with study design, data analysis performed, and approved the final version of the manuscript. PG Silva: helped with data analysis, reviewed the literature and approved the final version of the manuscript. KC Meira: designed the study, interpreted the data, led the data analysis and approved the final version of the manuscript.

\section{References}

1. Shneidman ES. Comprehending suicide: landmarks in 20th century suicidology. Washington, D.C.: American Psychological Association; 2001.

2. World Health Organization (WHO). Preventing suicide: a global imperative [Internet]. 2014 [cited 2019 Aug 29]. Available from: www.who.int/mental_health/suicide-prevention/world_report_2014/en/.

3. Brasil. Ministério da Saúde (MS). Secretaria de Vigilância em Saúde. Perfil epidemiológico das tentativas e óbitos por suicídio no Brasil e a rede de atenção à saúde [Internet]. 2017 [cited 2019 Sep 14]. Available from: http://portalarquivos2.saude.gov.br/images/ pdf/2017/setembro/21/2017-025-Perfil-epidemiologico-das-tentativas-e-obitos-por-suicidio-no-Brasil-e -a-rede-de-atencao-a-saude.pdf.

4. Alicandro G, Malvezzi M, Gallus S, La Vecchia C, Negri E, Bertuccio P. Worldwide trends in suicide mortality from 1990 to 2015 with a focus on the global recession time frame. Int J Public Health 2019; 64(5):785-795.

5. Vidal CEL, Gontijo ECDM, Lima LA. Tentativas de suicídio: fatores prognósticos e estimativa do excesso de mortalidade. Cad Saude Publica 2013; 29(1):175187.

6. Meneghel SN, Moura R, Hesler LZ, Gutierrez DMD. Tentativas de suicídio de mulheres idosas - na perspectiva de gênero. Cien Saude Colet 2015; 20(6):17211730.

7. Devries KM, Seguin M. Violence against Women and Suicidality: Does Violence Cause Suicidal Behaviour? In: Garcia-Moreno C, Riecher-Rossler A, editors. Violence against Women and Mental Health. Basel: Karger; 2013.

8. Nock MK, Borges L, Bromet EJ, Alonso J, Angermeyer $\mathrm{H}$, Beautrais AL, Bruffaerts R, Chiu WT, Girolamo G, Gluzman S, Graaf R, Gureje O, Haro JM, Huang Y, Karam E, Kessler RC, Lepine JP, Levinson D, Medina-Mora ME, Ono Y, Posada-Villa J, Williams D. Cross-national prevalence and risk factors for suicidal ideation, plans and attempts. Br J Psychiatry 2008; 192(2):98-105.

9. Silva RM, Sousa GS, Vieira LJES, Caldas JMP, Minayo MCS. Suicidal ideation and attempt of older women in Northeastern Brazil. Rev Bras Enferm 2018; 71(Supl. 2):755-762.

10. Meneghel SN, Gutierrez DMD, Silva RM, Grubits S, Hesler LZ, Ceccon RF. Suicídio de idosos sob a perspectiva de gênero. Cien Saude Colet 2012; 17(8):19831992.

11. Beautrais AL. Women and suicidal behavior. Crisis 2006; 27(4):153-156.

12. Bachmann S. Epidemiology of suicide and the psychiatric perspective. Int J Environ Res Saude Publica 2018; 15(7):1425.

13. Rodrigues CD, Souza DS, Rodrigues HM, Konstantyner TCRO. Trends in sulicide rates in Brazil from 1997 to 2015. Braz J Psychiatry 2019; 41(5):380-388.

14. GBD 2015 Mortality and Causes of Death Collaborators. Global, regional, and national life expectancy, allcause mortality, and cause-specific mortality for 249 causes of death, 1980-2015: a systematic analysis for the global burden of disease study 2015. Lancet 2016; 388(10053):1459-1544. 
15. Soares Filho AM, Cortez-Escalante JJ, França E. Review of deaths correction methods and quality dimensions of the underlying cause for accidents and violence in Brazil. Cien Saude Colet 2016; 21(12):3803-3818.

16. Queiroz BL, Freire FHMA, Gonzaga MR, Lima EEC. Estimativas do grau de cobertura e da mortalidade adulta (45q15) para as unidades da federação no Brasil entre 1980 e 2010. Rev Bras Epidemiol 2017; 20(Supl. 1):21-33.

17. Steeves GM, Petterini FC, Moura GV. The interiorization of Brazilian violence, policing, and economic growth. Economia 2015; 16(3):359-375.

18. Rockett IRH, Hobbs G, Leo D, Stack S, Frost JL, Ducatman AM, Kapusta ND, Walker RL. Suicide and unintentional poisoning mortality trends in the United States, 1987-2006: two unrelated phenomena? BMC Public Health 2010; 10:705.

19. Santos SA, Legay LF, Aguiar FP, Lovisi GM, Abelha L, Oliveira SP. Tentativas e suicídios por intoxicação exógena no Rio de Janeiro, Brasil: análise das informações através do linkage probabilístico. Cad Saude Publica 2014; 30(5):1057-1066.

20. Mathers CD, Fat DM, Inoue M, Rao C, Lopez AD. Counting the dead and what they died from: an assessment of the global status of cause of death data. Bull WHO 2005; 83(3):171-177.

21. Antunes JLF, Cardoso MRA. Using time series analysis in epidemiological studies. Epidemiol Serv Saude 2015; 24:565-576.

22. Magalhães AFC, Caldas ED. Underreporting of fatal poisonings in Brazil - A descriptive study using data from four information systems. Forensic Sci Int 2018; 287:136-141.

23. Im JS, Park BCB, Ratcliff KS. Cultural Stigma Manifested in Official Suicide Death in South Korea. OMEGA 2018; 77:386-403.

24. Brasil. Lei no 13.819, de 26 de abril de 2019. Institui a Política Nacional de Prevenção da Automutilação e do Suicídio, a ser implementada pela União, em cooperação com os Estados, o Distrito Federal e os Municípios; e altera a Lei no 9.656, de 3 de junho de 1998. Diário Oficial da União; 2019.

25. Wang Z, Chuanhua Y, Wang J, Bao J, Gao X, Xiang H. Age-period-cohort analysis of suicide mortality by gender among white and black Americans, 19832012. Int J Equity Health 2016; 15:1-9.

26. Katikireddi SV, Niedzwiedz CL, Popham F. Trends in population mental health before and after the 2008 recession: a repeat cross-sectional analysis of the 1991-2010. Health Surveys England 2012; 2:1-9.

27. Dantas AP, Azevedo UM, Nunes AD, Amador AE, Marques MV, Barbosa IR. Analysis of suicide mortality in Brazil: spatial distribution and socioeconomic context. J Bras Psiquiatr 2018; 40(1):12-18.
28. Santos EGO, Oliveira YMC, Azevedo UN. Nunes AD, Amador AE, Barbosa IR. Análise espaço-temporal da mortalidade por suicídio em idosos no Brasil. Rev Bras Geriatr Gerontol 2017; 20(6):854-865.

29. Chen YY, Kevin CC, Saman Y, Paul SF. Suicide in Asia: Opportunities and Challenges. Epidemiol Rev 2011; 34:129-144.

30. Brasil. Ministério da Saúde (MS). Agenda de ações estratégicas para vigilância e prevenção do suicídio e promoção da saúde no Brasil: 2017 a 2020. Brasília: MS; 2017.

31. Ribeiro JM, Marcelo R. Uma abordagem sobre o suicídio de adolescentes e jovens no Brasil. Cien Saude Colet 2018; 23(9):2821-2834.

32. Marquetti FR, Marquetti FC. Suicídio e feminilidades. Cad Pagu 2017; 49:e174921.

33. Botega NJ. Comportamento suicida: epidemiologia. Psicol USP 2014; 25(3):231-236.

34. Ribeiro NM, Castro SS, Scatena LM, Haas LM. Análise da tendência temporal do suicídio e de sistemas de informações em saúde em relação às tentativas de suicídio. Texto Contexto Enferm 2018; 27(2):e2110016.

35. Brasil. Lei no 10.826, de 22 de dezembro de 2003. Dispõe sobre registro, posse e comercialização de armas de fogo e munição, sobre o Sistema Nacional de Armas - Sinarm, define crimes e dá outras providências. Diário Oficial da União; 2003.

36. Machado DB, Santos DN. Suicide in Brazil, from 2000 to 2012. J Bras Psiquiatr 2015; 64(1):45-54.

37. Mann J. Michel J, Christina A. Prevention of Firearm Suicide in the United States: What Works and What Is Possible. Am J Psychiatr 2016; 173(10):969-979.

38. Brasil. Decreto $\mathrm{n}^{\circ} 9.847$, de 25 de junho de 2019. Regulamenta a Lei 10.826 sobre o cadastro, registro, porte e comercialização de armas de fogo e de munição, sobre o Sistema Nacional de Armas e o Sistema de Gerenciamento Militar de Armas. Diário Oficial da União 2019; 25 jun.

39. Dantas ESO. Prevenção do suicídio no Brasil: como estamos? Physis 2019; 29(3):e290303.

Article submitted 15/01/2020

Approved 24/08/2020

Final version submitted 26/08/2020

Chief editors: Romeu Gomes, Antônio Augusto Moura da Silva 